- włączenie rodziców do pracy wychowawczej szkoły;

- wypracowanie nowych metod, form i środków oddziaływania wychowawczego w procesie dydaktycznym, głównie poprzez pełnienie przez mlodzież określonych ról społecznych (wprowadzanie nauczania wychowującego);

- stworzenie niepowtarzalnej atmosfery wychowawczej.

Elżbieta Magiera w oparciu o przeprowadzone badania stwierdza, iż szkolnictwo powszechne po 1932 roku stanowiło główną droge ideologizacji polskiego społeczeństwa (s. 209).

Książa E. Magiery stanowi niewątpliwie cenna $\mathrm{i}$ interesująca pozycję, przydatna dla kandydatów na nauczycieli, studentów kierunków pedagogicznych, a przede wszystkim dla wszystkich nauczycieli-wychowawców oraz tych, którzy pragna modernizować polski system oświaty. Tworząc społeczeństwo obywatelskie, budujac koncepcję wychowania obywatelskiego, próbujac ożywiać życie szkolne w dzisiejszych szkołach III RP, warto sięgnąc do bogatych osiagnięć oświatowo-wychowawczych Drugiej Rzeczypospolitej, ukazanych między innymi w komplementamej i przedmiotowej monografii pt.: Wychowanie państwowe w szkolnictwie powszechnym Drugiej Rzeczypospolitej.

\section{Andrzej Kusztelak}

${ }^{1}$ Patrz m.in.: Trzebiatowski K.: Szkolnictwo powszechne $w$ Polsce $w$ latach 1918-1932, Wroclaw-Warszawa-Kraków 1970; Bartnicka Ka: Wychowanie państwowe, ,Rozprawy z Dziejów Oświaty" 1972, t. XV; Iwanicki M.: O ideowo-wychowawczym oddziatywaniu sanacji na mtodziez szkolna $i$ akademicka, Siedlce 1986; Araszkiewicz W.F.: Ideahy wychowawcze Drugiej Rzeczypospolitej, Warszawa 1978; Jakubiak K.: Wychowanie państwowe jako ideologia wychowawcza sanacji, Bydgoszcz 1994; Garbowska W.: Szkolnictwo powszechne w Polsce w latach 1932-1939. Wroclaw-Warszawa-Kraków-Gdańsk 1976; Sadowska J.: Ku szkole na miare Drugiej Rzeczypospolitej, Bialystok $2001 \mathrm{i}$ inne.

\title{
Pädagogik Unter den Linden. Von der Gründung der Berliner Universität im Jahre 1810 bis zum Ende des 20. Jahrhunderts, Hrsg. Klaus-Peter Horn, Heidemarie Kemnitz, Palas Athene - Beiträge zur Universitäts- und Wirtschaftsgeschichte, Bd. 6, Stuttgart 2002, ss. 314
}

Książka, pod nietypowym tytułem Pädagogik Unter den Linden dotyczy historii pedagogiki $w$ Uniwersytecie Humboldta w Berlinie, w okresie od jego założenia w 1810 roku do końca XX wieku. Przedstawiono, w niej prawie dwa wieki rozwoju tej dyscypliny ${ }^{1}$. Jest dziełem zbiorowym, a redaktorzy ${ }^{2}$ i autorzy ${ }^{3}$ przyjęli zasadę ukazania historii pedagogiki w perspektywie biograficznej, z niewielkimi odstępstwami na rzecz takich okresów w dziejach Niemiec, jak np. czasy narodowego socjalizmu i jego wpływ na sprawy nauki, a tym samym także pedagogiki. Jednak i tutaj jest to spojrzenie na historię ze wskazaniem na osoby działajace w tym okresie.

$W$ pracy zaprezentowano nazwiska, znane powszechnie $w$ historii pedagogiki, takie jak: Friedrich Eduard Beneke, Friedrich Daniel Ernst Schleiermacher, Friedrich Paulsen, Wilhelm Diel- they, Eduard Spranger, ale i mniej znanych pedagogów, zasłuzzonych jedynie dla pedagogiki berlińskiej, czy też niemieckiej.

Publikację rozpoczyna Wstęp autorstwa K.-P. Horna i H. Kemnitz, w którym przedstawiono rys rozwoju pedagogiki berlińskiej w XIX i XX wieku.

Następnie zamieszczono pięć studiów prezentujacych pedagogów działających w XIX wieku. I tak kolejno: artykuł redaktorki H. Kemnitz, poświęcony Johannowi Friedrichowi Wilhelmowi Himly, pierwszemu docentowi prywatnemu pedagogiki w tym Uniwersytecie (habilitowanemu w 1816 r.), który zaliczany jest do pestalocystów. Kolejny szkic, którego autorem jest Christoph Lüth, prezentuje Frierdicha Schleiermachera (ur. we Wroclawiu w 1768 r.), teologa $\mathrm{z}$ wyksztalcenia, który uczestniczył przy zakładaniu nowego uniwersytetu w Berlinie. Powolany w 1810 roku 
na stanowisko profesora teologii, wykłada aż do śmierci (1834 r.) oprócz teologii, filozofię i pedagogikę. Zdaniem autora szkicu dal podstawy nowożytnej pedagogiki. Jürgen Jahne poświęcił swój przyczynek F.E. Beneke (1798 - 1854), który pozostawał pod wplywem pism J. F. Herbarta, nie był jednak jego uczniem. Beneke za podstawe pedagogiki uznawał psychologię. Odnosząc się do relacji pedagogika i etyka twierdzil, że obie sa psychologia stosowana. Przykładem „arystotelizmu" w pedagogice XIX wieku, ukazanego przez Alfreda Langewanda, jest pedagogika Adolfa Trendelenburga (1802 - 1872), który przez wiele lat zajmował katedre filozofii w Berlinie. Był zdecydowanym przeciwnikiem J. F. Herbarta. I wreszcie Peter Drewek omówił filozofa i pedagoga przełomu XIX i XX wieku F. Paulsena (1846 - 1908), którego poglądy pedagogiczne można opisać jako relację między teorią kształcenia a historia kształcenia.

Autorzy kolejnych pięciu artykułów zaprezentowali pedagogikę i pedagogów XX wieku. Ich listę rozpoczyna znany filozof i pedagog Wilhelm Dielthey (1833-1911), który, jak powszechnie wiadomo, uznawany jest za twórcę nowoczesnej teorii poznania $w$ humanistyce. Ów przełom $w$ humanistyce wpłynął także na rozwój pedagogiki w XX wieku i wyodrębnienie się wśród różnych nurtów myślenia pedagogicznego pedagogiki kultury. Jego osobę i dzieło przedstawił Michael Winkler. Po zaprezentowaniu Dieltheya, uosabiającego teoretyczny wymiar pedagogiki, na karatach ksiażki czytelnik znajdzie informacje o pedagogice, której podstawę stanowi praktyka. Jej reprezentanta, Wilhelma Müncha przedstawil Andreas von Prondczynsky. Dwa następne omówienia H. E. Tenortha i K.-P Horna dotycza berlińskiej pedagogiki w okresie międzywojennym, a dokładniej z zaznaczeniem okresu do 1933 roku i od 1933 roku. Reprezentantem pierwszego okresu jest E. Spranger (1882 - 1963), który rozwiną tzw. ,psychologię rozumiejąca” i dokonał klasyfikacji osobowości. H. E. Tenorth prezentuje go w zwiazku z rozwojem pedagogiki w Uniwersytecie Berlińskim w latach 1913 - 1933. Okres drugi, czyli czasy pedagogiki (politycznej pedagogiki) w okresie narodowego socjalizmu, ukazane przez K.-P Horna, uosabia Alfred Baeumler (1887-1968), a instytucjonalnie powstanie instytutu nazwanego Institut für Politische Pädagogik.
I ostatni z tekstów ukazujących biografie i dzialalność pedagogów berlińskich, pióra Urlicha Wiegmanna, prezentuje Roberta Alta ( 1905 - 1978) i Heinricha Deitersa (1887 - 1966). Pierwszy $z$ nich, R. Alt zwiazany $z$ omawianym uniwersytetem w latach 1946-1970, drugi w latach 1946-1959. Obydwaj pedagodzy są reprezentantami pedagogiki socjalistycznej.

Ksiąikę kończa dwa teksty zamykające historię pedagogiki w Uniwersytecie Humboldta na latach 90-tych XX wieku. Redaktorzy i Olaf Kos przedstawili funkcjonowanie Sekcji Pedagogiki „F.A. Diesterwega” w latach 1968-1991 oraz stypendysta DAAD Japończyk Jun Yamana, który zaprezentowal spojrzenie na rozwój pedagogiki po roku 1989.

Zasadniczym kryterium porządkującym układ tekstów jest chronologia. Druga ważną przesłanka, która wynika także z historii tego Uniwersytetu i stanowi o treści tej publikacji, jest lista osób tworzących berlińską pedagogikę na przestrzeni dwustu lat. W wydawnictwie ukazany został wpływ, jaki wywarły opisywane osobistości świata pedagogicznego na kształtowanie się pedagogiki uniwersyteckiej.

Trzeba podkreślić, że omówiona, w dużym skrócie, ksiażka zasługuje na lekturę z kilku względów. Bowiem dzieje tej dyscypliny w omawianym uniwersytecie, potwierdzaja znaną już historykom pedagogiki tezę o związkach filozofii z pedagogiką i o udziale filozofów w rozwoju pedagogiki jako nauki. W pracy znajdujemy też materiał służący uzasadnieniu pogladu o niekorzystnym wpływie polityki na rozwój nauki. Publikacja niemieckich historyków pedagogiki jest znaczącym przyczynkiem $\mathrm{z}$ dziejów pedagogii europejskiej. Jest również przykładem opracowania, które stanowi ważne źródło do dalszych badań nad rozwojem nauki o wychowaniu.

\section{Wtadystawa Szulakiewicz}

\footnotetext{
1 Unter den Linden to nazwa ulicy.
}

2 Klaus-Peter Horn (1960-) jest pracownikiem naukowym Uniwersytetu Humboldta w Berlinie, Instytutu Nauki o Wychowaniu. Specjalizuje się w historii nauki o wychowaniu. Jest autorem m.in. Pädagogische Zeitschriften im Nationalsozialilismus. Selbstbehauptung, Anpassung, Funktionalisirung..., Weinheim 1996; Erziehungswissenschaft in Deutschland im 20. Jahrhundert. Zur Entwicklung der sozialen und fachlichen Struktur der Disziplin von der Erstinstitutionalisierung bis zur 
Expansion, Verlag Julius Klinkhardt, Bad Heilbrunn/OBB, 2003.

Heidemarie Kemnitz (1955-) jest docentem prywatnym w Instytucie Pedagogiki Ogólnej Uniwersytetu Humboldta. Autorka m.in.: Bildungsideen und Schullalltag im Revolutionsjahr, Baltmannsweiler 1999; Lehrerverein und Lehrerberuf im 19. Jahrhundert. Eine
Studie zum Verberuflichungsprozess der Lehrehrtätigkeit am Beispiel der Berlinischen Schullehrergesellschaft (1813-1892), Weinheim 1999.

${ }^{3}$ Wśród autorów artykułów warto wskazać na badaczy znanych z publikacji dotyczacych historii edukacji m.in.: Christoph Luth, Heinz-Elmar Tenorth, czy wspomniany K.-P Horn.

\section{Rola szkolnictwa łódzkiego w tworzeniu dziedzictwa kulturowego Łodzi w XX wieku. Tradycje i współczesność łódzkich szkół średnich, red. Tadeusz Jałmużna, Lódzkie Towarzystwo Naukowe, Łódź 2003, ss. 353}

W kwietniu 2003 roku Łódzkie Towarzystwo Naukowe wydało pracę pt. „Rola szkolnictwa łódzkiego $w$ tworzeniu dziedzictwa kulturowego Łodzi w XX wieku. Tradycje i współczesność łódzkich szkół średnich".

Pozycja składa się z trzech części, z których każda porusza inna przestrzeń działalności szkolnictwa lódzkiego i jego twórców. Również czasowo, jak sam tytuł wskazuje, książka obejmuje wlaściwie prawie cały wiek $\mathrm{XX}$ oraz pierwsze „chwile" wieku XXI.

Część pierwsza, opatrzona tytułem „Pozadydaktyczna działalność nauczycieli”, zawiera sześć artykułów. Wśród nich poruszane sa problemy tradycji w pedagogice ujęte jako problemy metodologiczne, zagadnienia dotyczące miejsca nauczycieli szkół średnich ogólnokształcących w społeczeństwie Polski międzywojennej, informacje na temat łódzkiej szkoły średniej w lokalnej prasie codziennej Drugiej Rzeczypospolitej, działalność Towarzystwa Nauczycieli Szkół Średnich i Wyższych w Lodzi w okresie międzywojennym, średnie szkoły ogólnokształcące dla mniejszości narodowych mieszkających w Łodzi w w/w okresie, czy innowacje pedagogiczne w szkołach średnich miasta Łódź w latach $1970-2000$.

W tej części interesujace jest zaprezentowane przez Wiesławę Leżańską stanowisko nauczycieli szkół średnich w Łodzi w okresie międzywojennym, którzy, starając się odcinać od wszelkich rozgrywek politycznych, popularyzowali wiedzę, integrowali grupy społeczne, kształtowali poczucie jedności narodowej. Autorka wskazuje jak bardzo ważna była praca wychowawców w warunkach odradzającej się państwowości polskiej, jak istotne bylo rozwijanie intelektualnych zdolności swoich wychowanków, ułatwianie adaptacji do nowych warunków życia i pracy, rozwijanie zainteresowań, kształtowanie poglądów. Pomimo stosunkowo niskiej stabilizacji zawodu nauczycielskiego w owym okresie, starali się oni wypełniać swe obowiazki z poświęceniem i odpowiedzialnością, co należycie przedstawia W. Leżańska.

Iwonna Michalska udowadnia w swej pracy, jak cennym źródłem poznania minionej rzeczywistości oświatowej są czasopisma, a wśród nich zwłaszcza periodyki oświatowo-pedagogiczne i pedagogiczne wydawane przez władze szkolne, stowarzyszenia, zwiazki nauczycielskie, organizacje społeczne, czy osoby prywatne. Autorka słusznie zwraca uwage na istotę owych wydawnictw, w których odnotowywane sa często rzeczy drobiazgowe, wydawałoby się nieistotne, których nie znajdziemy w innych dokumentach czy kronikach. Informacje te jednak pozwalaja badaczowi „poczuć" klimat, jaki w badanej rzeczywistości miał miejsce, pozwalaja mu zrozumieć wiele wydarzeń, które zamieszczone w dokumentach czy kronikach, często owych „emocji”, jakie im towarzyszyły, nie posiadaja.

Działalność Towarzystwa Nauczycieli Szkół Średnich i Wyższych w Łodzi w okresie międzywojennym zaprezentował Grzegorz Michalski, ukazując poważne zaangażowanie Towarzystwa w sprawy naukowe, zawodowe, kształcenia i dokształcania kadr pedagogicznych oraz problemy 